\title{
Untreated Childhood Anaplastic Oligoastrocytoma
}

National Cancer Institute

\section{Source}

National Cancer Institute. Untreated Childhood Anaplastic Oligoastrocytoma. NCI

Thesaurus. Code C115920.

A finding of anaplastic oligoastrocytoma in childhood that has not been treated. 